Mikrobiologiczna diagnostyka zakażeń wywoływanych przez Listeria monocytogenes

\title{
Microbiological diagnosis of infections caused by Listeria monocytogenes
}

Natalia Rokosz-Chudziak, Waldemar Rastawicki, Karolina Śmietańska

Zakład Bakteriologii i Zwalczania Skażeń Biologicznych,

Narodowy Instytut Zdrowia Publicznego - Państwowy Zakład Higieny w Warszawie

Pałeczki Listeria monocytogenes to Gram-dodatnie bakterie, szeroko rozpowszechnione w środowisku naturalnym (gleba, woda, ścieki, rośliny i warzywa, produkty spożywcze), wywołujące u czlowieka chorobę zwaną listeriozą. Listerioza objawia się najczęściej w postaci bakteremii, zapalenia opon mózgowo-rdzeniowych i mózgu, zakażeń okołoporodowych a także nieżytu żołądkowo-jelitowego. W pracy przedstawiono metody mikrobiologicznej diagnostyki zakażeń wywołanych przez pałeczki Listeria monocytogenes u ludzi.

Słowa kluczowe: Listeria monocytogenes, diagnostyka mikrobiologiczna, listerioza

\section{ABSTRACT}

Listeria monocytogenes are Gram-positive, relatively anaerobic bacteria, widely distributed in the natural environment (soil, water, sewage, plants and vegetables, food products), causing a disease called listeriosis in humans. Listeriosis is manifested most often in the form of bacteremia, meningitis and encephalitis, perinatal infections as well as gastroenteritis. Currently, it is perceived as a contemporary threat to human life and health. This review discusses the microbiology diagnosis of infections caused by Listeria monocytogenes in humans.

Keywords: Listeria monocytogenes, microbiology diagnosis, literiosis

\section{WSTĘP}

Drobnoustroje znane obecnie jako Listeria monocytogenes po raz pierwszy wyizolowano w 1924 roku od chorujących na posocznicę królików i świnek morskich. Dwa lata później Murray opisał te Gram-dodatnie pałeczki jako Bacterium monocytogenes, a dopiero w 1940 roku Harvey Pirie zmienił nazwę rodzaju na Listeria $(3,4,9)$. Do 1961 roku 
L. monocytogenes była jedynym przedstawicielem rodzaju Listeria $\mathrm{sp}$. W następnych latach włączono do rodzaju Listeria kolejnych kilkanaście gatunków, w tym między innymi: L. grayi, L. innocua, L. welshimer, L. seeligeri i L. ivanovii $(9,14)$.

Pałeczki L. monocytogenes są etiologicznym czynnikiem listeriozy, choroby przenoszącej się głównie drogą pokarmową, stanowiącej istotny problem zdrowia publicznego w wielu krajach $(1,2,5,9)$. Częste zanieczyszczenie produktów pochodzenia zwierzęcego pałeczkami Listeria wymusza konieczność kontroli żywności pod kątem obecności tych drobnoustrojów $(1,2,4,5,9)$.

Najważniejszą cechą chorobotwórczych gatunków Listeria jest zdolność do namnażania się zarówno w środowisku zewnętrznym jak i w organizmach żywych. Istotny jest też problem bezobjawowego nosicielstwa, najczęściej w przewodzie pokarmowym ludzi i zwierząt. Szacuje się, że u ludzi zjawisko to dotyczy około $5-10 \%$ populacji $(2,9)$. Jak wynika z najnowszych danych European Centre for Disease Prevention and Control (ECDC), wskaźnik zachorowalności na listeriozę w krajach Unii Europejskiej i krajach stowarzyszonych (EEA/EFTA) w 2015 roku wynosił 0,5 na 100.000 mieszkańców (2). Niestety, choroba ta charakteryzuje się znaczną śmiertelnością (20-30\%) i wysokim odsetkiem hospitalizacji $(97,4 \%)(2,9)$. W Polsce, w 2017 roku odnotowano 123 przypadki listeriozy, z czego aż 120 (97,6\%) osób było hospitalizowanych. Zapadalność na listeriozę w naszym kraju w 2017 roku wyniosła 0,32 na 100.000 mieszkańców (19).

Chorobotwórczość pałeczek L. monocytogenes związana jest z występowaniem u tych patogenów szeregu czynników zjadliwości, między innymi takich jak:

1. internalina (Inl) - jest to białko powierzchniowe ułatwiające adherencję i wnikanie bakterii do komórek eukariotycznych,

2. białko powierzchniowe ActA - białko zlokalizowane na jednym z końców pałeczki, indukujące w cytoplazmie komórki gospodarza polimeryzację aktyny; wytworzony tzw. ogon aktynowy, określany jako „kometa listeryjna”, umożliwia komórce przemieszczanie się i rozprzestrzenianie między komórkami,

3. listeriolizyna $\mathrm{O}$ (LLO) - jest to egzotoksyna odpowiedzialna za przerywanie błon fagolizosomów,

4. egzoenzymy: fosfolipazy w tym fosfolipaza C (PLC), umożliwiająca zakażanie kolejnych komórek bez groźby zniszczenia przez komórki układu immunologicznego gospodarza $(3,6,13,17)$.

Do klinicznych postaci listeriozy u ludzi mogących mieć bardzo poważne następstwa zalicza się bakteremię, zapalenie opon mózgowo-rdzeniowych, zapalenie mózgu oraz zakażenia okołoporodowe. Okołoporodowa listerioza noworodków może przebierać formę o wczesnym lub późnym początku. Wcześniejsza jest wynikiem wewnątrzmacicznego zakażenia i objawia się na ogół jako sespsa. Późniejsza postać, nabywana w trakcie lub tuż po porodzie, rozwija się w drugim lub trzecim tygodniu życia dziecka, w większości przypadków jako zapalenie opon mózgowo-rdzeniowych $(3,9,15)$. Listerioza może też być przyczyną poronień. Poza wymienionymi powyżej postaciami klinicznymi pałeczki L. monocytogenes mogą wywołać zapalenie żołądka i jelit, zapalenie wsierdzia, zapalenie otrzewnej, zapalenie oraz ropień wątroby, infekcje skórne oraz infekcje mięśniowo-szkieletowe $(3,6,7,9,17,13)$. Ze względu na przebieg choroby możemy wyróżnić następujące postaci listeriozy: ostrą, podostrą, przewlekłą z nawrotami lub poronną (3).

Pierwsze objawy u osób dorosłych po zakażeniu drogą pokarmową występują po upływie 24-48 godzin od spożycia skażonej żywności. Mogą wystąpić wówczas niecharaktery- 
styczne objawy, takie jak: ból stawów, ból głowy, umiarkowana biegunka, gorączka, inne objawy żołądkowe czy senność. Najczęściej objawy samoistnie ustępują, czasami jednak listerioza może mieć ciężki przebieg, zwłaszcza o osób z grup ryzyka, takich jak noworodki, osoby starsze, kobiety w ciąży czy pacjenci o upośledzonej odporności $(7,13)$.

W 2018 roku na potrzeby nadzoru epidemiologicznego przyjęto następującą definicję listeriozy (19):

Kryteria kliniczne:

Każda osoba, która spełnia co najmniej jedno z następujących trzech kryteriów:

Listerioza noworodków - definiowana jako urodzenie martwe lub co najmniej jedno z następujących pięciu kryteriów w ciągu pierwszego miesiąca życia:

- ziarniniakowatość (granulomatosis infantiseptica),

- zapalenie opon mózgowo-rdzeniowych lub zapalenie opon i mózgu,

- posocznica,

- duszność,

- zmiany skórne, błon śluzowych lub spojówek,

Listerioza u kobiet $\mathbf{w}$ ciąży - definiowana jako jedno z następujących trzech kryteriów:

- poronienie, przedwczesne zakończenie ciąży, urodzenie martwe lub poród przedwczesny,

- gorączka,

- objawy grypopodobne,

Inne postaci listeriozy - definiowane jako jedno z następujących czterech kryteriów:

- gorączka,

- zapalenie opon mózgowo-rdzeniowych lub zapalenie opon i mózgu,

- posocznica,

- zakażenia miejscowe, takie jak zapalenie stawu, zapalenie wsierdzia oraz ropnie.

Kryteria laboratoryjne

Co najmniej jedno z następujących dwóch kryteriów:

- izolacja Listeria monocytogenes z miejsca, które w warunkach prawidłowych jest jałowe,

- izolacja Listeria monocytogenes z miejsca, które w warunkach prawidłowych nie jest jałowe u płodu, płodu martwo urodzonego, niemowlęcia lub matki w ciągu 24 godzin od porodu.

Kryteria epidemiologiczne

Co najmniej jedno z następujących trzech powiązań epidemiologicznych:

- narażenie przez to samo źródło,

- przeniesienie z człowieka na człowieka (zakażenie wertykalne),

- narażenie przez skażoną żywność/ wodę pitną.

Informacje dodatkowe; okres inkubacji: od 3 do 70 dni, najczęściej 21 dni.

Klasyfikacja przypadku:

A. Przypadek możliwy- nie dotyczy.

B. Przypadek prawdopodobny: każda osoba spełniająca kryteria kliniczne i epidemiologiczne.

C. Przypadek potwierdzony: każda osoba spełniająca kryteria laboratoryjne lub każda matka, w wypadku której zakażenie płodu, dziecka martwo urodzonego lub niemowlęcia zostało potwierdzone laboratoryjnie. 


\section{DIAGNOSTYKA LABORATORYJNA}

Rozpoznanie listeriozy stawiane jest na podstawie wywiadu lekarskiego, obrazu klinicznego oraz wyników badań laboratoryjnych. Ze względu jednak na znaczne zróżnicowanie objawów klinicznych, podstawą rozpoznania są wyniki badań hodowlanych, genetycznych lub znacznie rzadziej serologicznych (4).

\section{Materiał kliniczny do badań}

Rodzaj próbek materiału klinicznego do badań mikrobiologicznych, w których poszukuje się pałeczek Listeria, zależy od diagnozowanej postaci listeriozy. W postaci nieokołoporodowej (zapalenie centralnego układu nerwowego, posocznica) pałeczki Listeria izoluje się z materiałów klinicznych takich jak: krew, płyn mózgowo-rdzeniowy czy bioptaty z narządów wewnętrznych $(4,13,17) \mathrm{W}$ przypadku zatrucia pokarmowego materiałem do badań mikrobiologicznych jest kał $(13,18)$. U dzieci z podejrzeniem infekcji wrodzonej powinno się wykonać zaraz po urodzeniu posiew smółki, moczu bądź aspiratu z żołądka. W przypadku wczesnej listeriozy noworodków bada się wody płodowe, smółkę, krew dziecka i matki, materiał z pochwy i macicy. Pomocne może być także wykonanie preparatu bezpośredniego z wymazu z gardła i worka spojówkowego noworodka, a także ze smółki, z ropy ze zmian na skórze oraz z osadu uzyskanego po odwirowaniu płynu mózgowo-rdzeniowego $(16,17)$.

\section{Badania mikroskopowe}

Preparat barwiony metodą Grama. Bakterie z rodzaju Listeria to Gram-dodatnie, krótkie pałeczki o długości 1,2 $\mu \mathrm{m}$ i szerokości $0,5 \mu \mathrm{m}$, które zazwyczaj występują pojedynczo lub tworzą krótkie łańcuszki. Mogą też organizować się w skupiska palisadowe i przyjmować kształt litery V i Y (14). W preparatach z materiałów klinicznych często są widoczne wewnątrz komórki, układając się parami, mogą przypominać pneumokoki (16). W preparacie z płynu mózgowo-rdzeniowego zabarwionym metodą Grama bakterie nie są wykrywalne z powodu bardzo małej liczby $\left(<10^{4}\right)(18)$.

Preparat przyżyciowy $\mathbf{z}$ hodowli. Istnieje możliwość obserwacji w mikroskopie świetlnym wirowego ruchu postępowego pałeczek Listeria w preparacie przyżyciowym w kropli 0,85\% NaCl. Do wykonania tego preparatu używa się 18-24 godzinnej hodowli pałeczek Listeria w temp. $37^{\circ} \mathrm{C}$ na podłożu Columbia Agar z krwią baranią (18).

\section{Hodowla}

Pałeczki Listeria można hodować w warunkach tlenowych lub bez obecności tlenu. Lepiej namnażają się w atmosferze uzupełnionej 5-10\% $\mathrm{CO}_{2}$ Rosną dobrze na zwykłych podłożach, chociaż w przypadku próbek materiału klinicznego zawierających dużą liczbę drobnoustrojów towarzyszących zaleca się stosowanie podłóż wybiórczych i przechowywanie próbek przed wykonaniem posiewu w niskich temperaturach (w lodówce). Pałeczki Listeria nie wymagają do wzrostu pożywek wzbogaconych, ale ze względów praktycznych hoduje się je na agarze z krwią, na którym można zaobserwować wąski rąbek hemolizy typu $\beta$ wokół drobnych (1-1,5 mm) kolonii L. monocytogenes. Do pożywek z krwią nie powinno się używać agaru tryptozowo-sojowego (TSA), ponieważ zawarta w nim celobioza powoduje represję genu hemolizyny. Krwinki powinny być przepłukane fizjologicznym roztworem soli, gdyż w organizmach zwierząt od których są pobierane, często występują 
przeciwciała hamujące wzrost pałeczek Listeria. Na pożywkach bez krwi kolonie są szaro-niebieskawe, a w świetle przechodzącym niebiesko-zielone $(4,16,18)$.

Pałeczki Listeria mogą się nammnażać w szerokim zakresie wartości pH (pH 6-9) i szerokim zakresie temperatur $\left(1-45^{\circ} \mathrm{C}\right)$. Tę ostatnią cechę wykorzystuje się w diagnostyce listeriozy. Materiał kliniczny, zmieszany w proporcji 1:10 z bulionem, umieszcza się w temperaturze $4^{\circ} \mathrm{C}$. Pałeczki Listeria mnożą się w niskich temperaturach w przeciwieństwie do innych drobnoustrojów izolowanych z organizmu człowieka. Co kilka dni zakłada się subkultury na agarze z krwią lub pożywkach selektywnych zawierających antybiotyki, najczęściej kolistynę i kwas nalidyksowy (Agar CNA, bulion LE (ang. Listeria enrichment broth), podłoże według Van Nettena). Podłoża te, a także pożywki z substratami chromogennymi, są też używane do bezpośredniego posiewu próbek klinicznych $(4,16,18)$.

Do izolacji stosuje się stałe podłoże diagnostyczno-wybiórcze PALCAM Agar według Van Nettena $(4,11,18)$. Czynnikami selektywnymi w tym podłożu są antybiotyki polimyksyna B i ceftazydym, barwnik akryflawina oraz chlorek litu, natomiast czynnikiem różnicującym jest m.in. eskulina (18).. Hodowle można inkubować w warunkach tlenowych lub w atmosferze wzbogaconej w $\mathrm{CO}_{2}$, przez 48 godzin w temperaturze $35^{\circ} \mathrm{C}$. Kolonie pałeczek Listeria na podłożu PALCAM są małe, połyskujące, szarozielone, o równym brzegu. Charakterystyczną, morfologiczną cechą kolonii L. monocytognes jest czarne zabarwienie środka oraz wyraźne czarne halo wokół niej. Zaczernienie powstaje w wyniku hydrolizy eskuliny - cechy charakterystycznej dla wszystkich pałeczek Listeria (Fot. 1) $(4,16,17,18)$. W celu oceny udziału bakterii $\beta$-hemolizujących we florze kolonizującej układ pokarmowy u chorych leczonych antybiotykami oraz pacjentów oddziałów intensywnej terapii próbki kału lub wymazu posiewane są dodatkowo na podłoże agarowe z krwią. Hodowlę prowadzi się w temperaturze $37^{\circ} \mathrm{C}$ przez 24 - 48 godzin $(4,16)$.

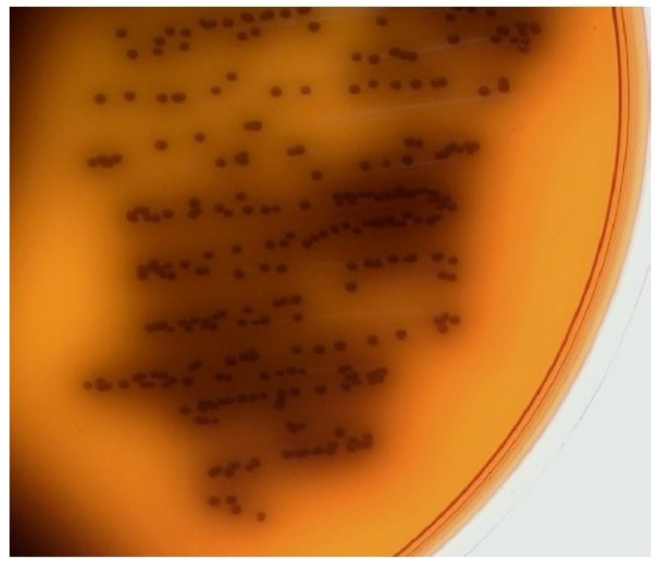

Fot. 1. Wzrost pałeczek Listeria monocytogenes na podłożu PALCAM (18).

Posiew podpowierzchniowy, czyli tzw. posiew kłuty, L. monocytognes na podłoże półpłynne (0,2 - 0,4\% agar z peptonem), umożliwia po 24 - 48 godzinnej inkubacji w temperaturze pokojowej (optimum $25^{\circ} \mathrm{C}$ ), wykazanie charakterystycznego dla pałeczek Listeria ruchu w kształcie „parasola” (Fot.2). W temperaturze $37^{\circ} \mathrm{C}$ większość szczepów L. monocytogenes jest nieruchliwa $(4,17)$. Schemat posiewu próbki kału i identyfikacji wybranych gatunków pałeczek Listeria przedstawia Rycina 1 (18). 


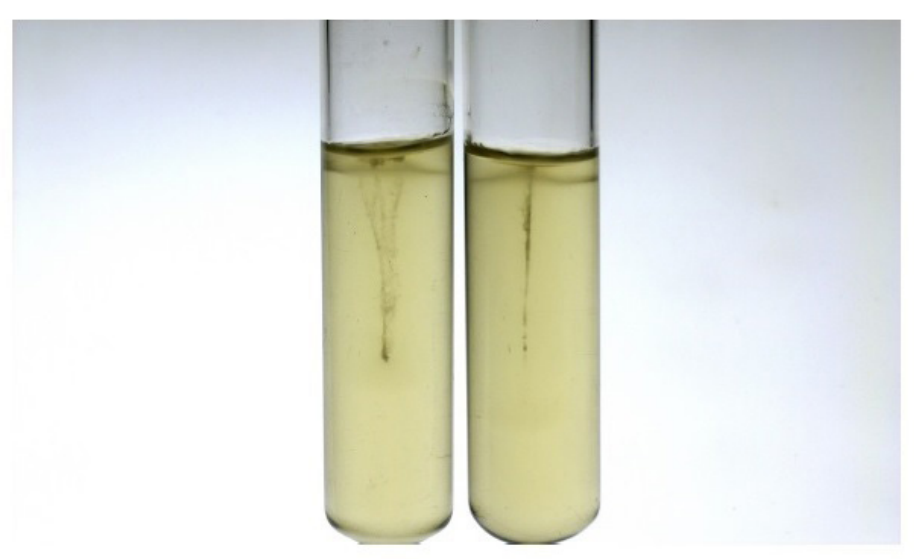

Fot. 2. Wynik testu na ruchliwość pałeczek Listeria monocyglogenes (18).

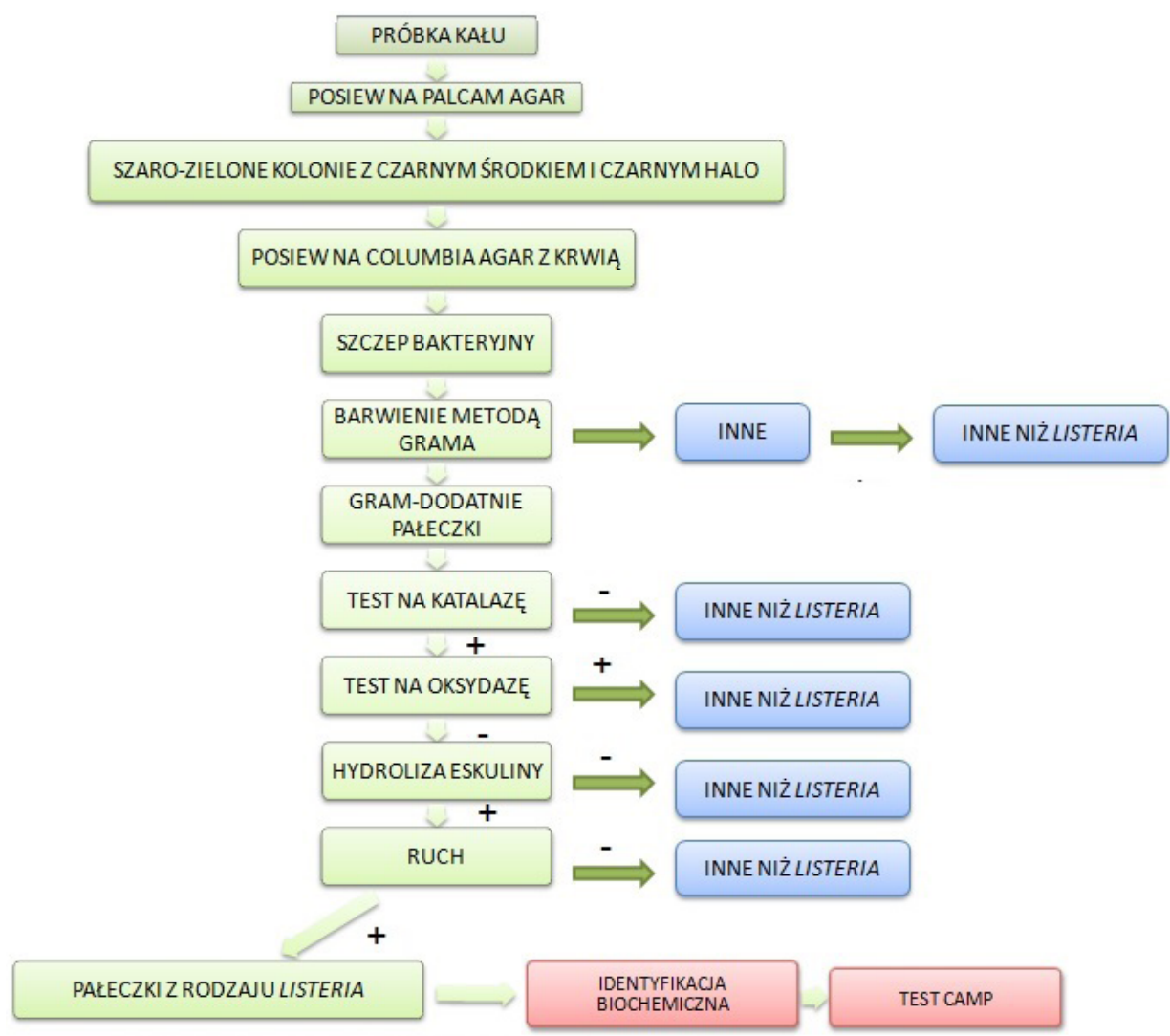

Ryc. 1. Schemat posiewu próbki kału w kierunki pałeczek Listeria (18). 
W celu potwierdzenia identyfikacji pałeczek $L$. monocytogenes wykonuje się test CAMP (Christie, Atkins, Munch-Petersen) polegający na wykrywaniu wzmocnienia hemolizy szczepów $L$. monocytogenes lub $L$. ivanovii przez $\beta$-hemolityczny wywołanej przez szczep Staphylococcus aureus oraz szczep Rhodococcus equi. W celu wykonania testu posiewa się pionowymi liniami $\beta$-hemolityczny szczep $S$. aureus oraz szczep $R$. equi na podłoże Columbia Agar z 5\% dodatkiem krwi baraniej. Poprzecznie do nich, w odległości 2-3 mm (między liniami posiewu), posiewa się badane szczepy pałeczek Listeria. Wzmocnienie hemolizy od strony $S$. aureus i brak wzmocnienia dla $R$. eui jest cechą charakterystyczną dla $L$. monocytogenes. Silne wzmocnienie hemolizy od strony $R$. equi (w postaci kapelusza grzyba) jest potwierdzeniem, iż szczepem jest $L$. ivanovii. Natomiast $L$. innocua nie daje wzmocnienia hemolizy z obydwoma szczepami wzorcowymi. Schemat wykonania oznaczenia i interpretacji testu CAMP przedstawia Rycina $2(4,18)$.

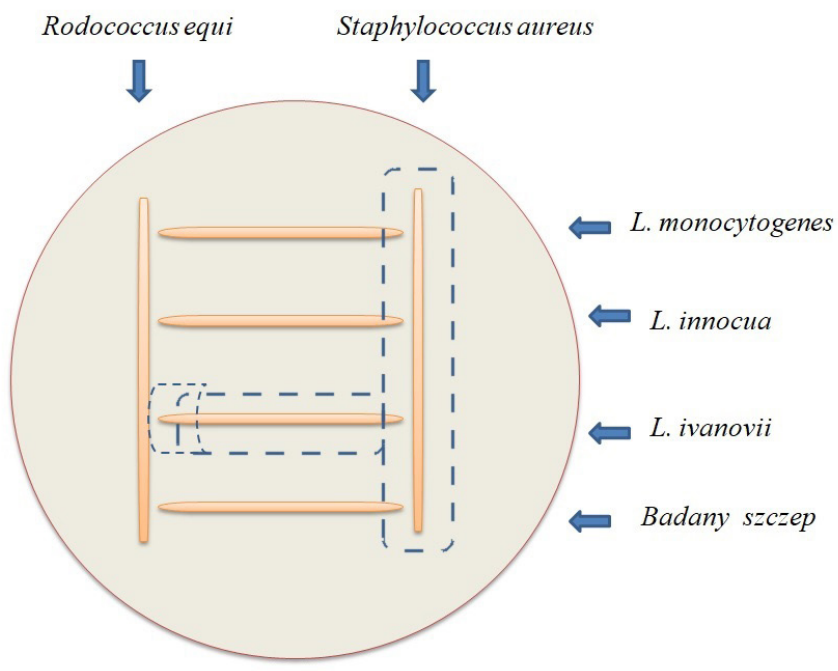

Ryc. 2. Schemat wykonania i interpretacji testu CAMP (8)

\section{Identyfikacja biochemiczna}

Właściwości biochemiczne najczęściej izolowanych od człowieka pałeczek Listeria oznacza się podstawowymi testami na aktywność katalazy, aktywność oksydazy, hydrolizę eskuliny, fermentację D-ksylozy, fermentację L-ramnozy, fermentację D-rybozy i hydrolizę hipuranu $(4,12,18)$. Obecnie dostępne są dwa typy szybkich testów wykorzystujących profil biochemiczny badanych drobnoustrojów do identyfikacji pałeczek Listeria - automatyczne w systemie VIDAS (bioMerieux) i manualne. Różnią się one odmiennym sposobem odczytu wyniku reakcji. W systemie VIDAS zmiana reakcji barwnej odczytywana jest przez urządzenie natomiast $\mathrm{w}$ systemie manualnym przez osobę wykonującą test. W Polsce jako pierwsze na rynku pojawily się testy manualne z serii API firmy bioMerieux. Obecnie dostępne są też testy MIcrobact Listeria 12L (Oxoid) oraz Microgen Listeria ID MID-67c (Microgen Bioproducts) (11). 


\section{Systemy automatyczne do identyfikacji}

Próbki materiału klinicznego naturalnie jałowe (krew, płyn mózgowo-rdzeniowy) można badać w kierunku obecności Listeria monocytogenes z wykorzystaniem systemów automatycznych, np. BACT/Alert, BD Bactec, MicroScan (Baxter Healthcare Corporation,), Vitek (bioMerieux), MicroStation (Biolog, Heyward) and Cobas (Becton Dickinson Instrument Systems) $(11,16,17)$.

\section{Diagnostyka serologiczna zakażenia Listeria monocytogenes}

Według Światowej Organizacji Zdrowia badania serologiczne mające na celu oznaczenie poziomu przeciwciał anty-L. monocytogenes nie mają większego znaczenia diagnostycznego w rozpoznaniu listeriozy, aczkolwiek w przypadku wczesnej listeriozy wykrycie przeciwciał w surowicy krwi matki i dziecka daje możliwość szybkiej diagnozy $(4,16,17)$.

Do wykrywania przeciwciał dla listeriolizyny O wykorzystuje się test pośredni ELISA. Jednakże ze względu na antygenowe pokrewieństwo listeriolizyny O ze streptolizyną Streptococcus pyogenes, pneumolizyną $S$. pneumoniae czy perfringolizyną Clostridium perfringenfs, swoistość testu jest niska (5). W niektórych laboratoriach (m.in. w Laboratorium Zakładu Bakteriologii i Zwalczania Skażeń Biologicznych NIZP-PZH w Warszawie) stosowany jest odczyn mikroaglutynacji jako test wykrywający w surowicy krwi przeciwciała swoiste dla antygenów pałeczek $L$. monocytogenes i $L$. ivanovii.

$\mathrm{W}$ badaniach serologicznych wykorzystuje się również odczyn immunofluorescencji z płynem mózgowo-rdzeniowym czy odczyn wiązania dopełniacza z surowicą krwi. Bardzo czuła jest metoda immunohistochemiczna wykorzystywana do wykrywania antygenów $L$. monocytogenes $\mathrm{w}$ utrwalonych formaliną preparatach pobranych z układu nerwowego $(4,5)$.

\section{Typowanie serologiczne}

Szczepy L. monocytogenes różnią się między sobą determinantami antygenowymi znajdującymi się na powierzchni komórki. Izolaty rozpoznane biochemicznie mogą podlegać dalszej identyfikacji serologicznej klasyczną metodą serotypowania opierającą się na wykorzystaniu metody aglutynacji szkiełkowej do identyfikacji antygenów somatycznych oraz aglutynacji probówkowej do identyfikacji antygenów rzęskowych $(4,10)$. Serotyp determinowany jest odpowiednią kombinacją ciepło-stabilnego antygenu somatycznego $\mathrm{O}$ oraz ciepło-labilnego antygenu rzęskowego $\mathrm{H}(1,4,14)$. Wśród szczepów $L$. monocytogenes wyróżniono 13 serotypów: 1/2a, 1/2b, 1/2c, 3a, 3b, 3c, 4a, 4b, 4c, 4d, 4ab i 7. Ze wszystkich serotypow dla człowieka najbardziej niebezpieczne uważane są 1/2a, 1/2b i 4b, którym przypisuje się $95 \%$ przypadków listeriozy u ludzi, z czego serotyp $4 \mathrm{~b}$ jest odpowiedzialny za 50\% zachorowań na listeriozę na świecie $(1,4,9,10,14)$.

\section{Metody biologii molekularnej}

W diagnostyce listeriozy zastosowanie znalazła również metoda PCR, a także typowanie metodami molekularnymi, które jest bardzo ważne podczas dochodzenia epidemiologicznego. Przy użyciu gatunkowo-specyficznego PCR możliwa jest identyfikacja bakterii do poziomu gatunku. Istnieje również możliwość użycia sond genetycznych wykrywających w badanym materiale geny sterujące syntezą białka p60, a także fragmenty sekwencji nukleotydowych genu kodującego listeriolizynę hlyA i genu kodującego białko regulatorowe dla tej toksyny prfA. Stosuje się również techniki umożliwiające wykrycie fragmentów wielu genów (multiplex PCR) $(1,4,10,16,18)$. 
Dostępne genetyczne metody subtypowania pozwalają na poznanie elementów genomiki, epidemiologii oraz ekologii pałeczek L. monocytogenes. Stosowanie technik molekularnych pozwala na szybsze i skuteczniejsze wykrywanie i opracowywanie epidemicznych ognisk wywoływanych przez zakażenie pałeczkami tego gatunku $(1,4,8)$. Opisanych jest przynajmniej kilka metod genotypowania pałeczek z rodzaju Listeria, wśród których najczęściej wymienia się: analizę makrorestrykcyjną genomowego DNA z zastosowaniem elektroforezy w zmiennym polu elektrycznym (REA- PFGE), rybotypowanie, metody bazujące na technice łańcuchowej reakcji polimerazy, jak również metody MLVA (Multiple-Locus Variable-number tandem-repeats Analysis), MLST (Multilocus Sequence Typing) wraz z ich odmianami. Metoda MLST polega na porównaniu wysoce stabilnych sekwencji alleli wybranych genów typu „housekeeping” - kodujących białka biorące udział w podstawowym metabolizmie, warunkującym przeżycie komórki. Technika MLVA opiera się na analizie tandemowych powtórzeń, znajdujących się w DNA. Wykorzystywana jest głównie w celu ustalenia fillogenetycznego pochodzenia badanych szczepów $(4,8)$.

Analiza polimorfizmu długości restrykcyjnych fragmentów chromosomalnego DNA w zmiennym polu elektrycznym (REA-PFGE) stosowana jest $\mathrm{w}$ toku dochodzenia epidemiologicznego w przypadku zakażeń pałeczkami Listeria monocytogenes. Jest ona bardzo przydatna zarówno $\mathrm{w}$ odniesieniu do szczepów pochodzących $\mathrm{z}$ ognisk epidemicznych wywołanych przez pałeczki Listeria monocytogenes jak i sporadycznych przypadków listeriozy (8).

W celu szybkiego porównania pokrewieństwa szczepów wykorzystuje się inne metody genotypowania, oparte na technice łańcuchowej reakcji polimerazy (PCR). Najważniejsze metody w odniesieniu do szczepów pałeczek Listeria monocytogenes to: metody Multiplex PCR, AFLP (Amplified Fragments Length Polymorphism - polimorfizm długości fragmentów amplifikowanych), PCR-RFLP (Polymerase Chain Reaction - łańcuchowa reakcja polimerazy- polimorfizm długości fragmentów restrykcyjnych) oraz metody z grupy RAPD (Random Amplification of Polymorphic DNA - losowa amplifikacja polimorficznych fragmentów DNA), wśród których do najpowszechniej stosowanych zaliczane są: RAPD-PCR, AP-PCR, rep--PCR oraz ERIC-PCR $(4,8)$.

\section{PODSUMOWANIE}

Diagnostyka mikrobiologiczna zakażeń pałeczkami Listeria monocytogenes obejmuje przede wszystkim metody izolacji i identyfikacji bakterii z próbek materiału klinicznego. Stosowanie metod biologii molekularnej pozwala na szybkie i skuteczniejsze wykrywanie i opracowywanie epidemicznych ognisk wywoływanych przez zakażenie pałeczkami $L i$ steria. Metody serologiczne nie mają większego znaczenia diagnostycznego w rozpoznaniu listeriozy.

\section{PIŚMIENNICTWO}

1. European Centre for Disease Prevention and Control. Fifth external quality assessment scheme for Listeria monocytogenes typing. Sztokholm: ECDC; 2018.

2. European Centre for Disease Prevention and Control. Listeriosis. In: ECDC. Annual epidemiological report for 2015. Sztokholm: ECDC; 2018. 
3. Galińska E, Knap J, Stroczyńska-Sikorska M. Listerioza - mało znana, niebezpieczna choroba zakaźna. Medycyna Ogólna 2010; 16(XLV), 4.

4. Gasanov U, Hughes D, Hansbro P. Methods for the isolation and identyfication of Listeria spp. and Listeria monocytogenes: a review. FEMS Microbiol Rev 2005; 29: 851-75.

5. Gliński Z, Kostro K. Listerioza współczesnym zagrożeniem. Życie Weterynaryjne 2012; 87: (7).

6. Heczko i wsp. Mikrobiologia lekarska. PWZL, 2016, s.123-24.

7. Kołakowska A, Madajczak G. Pałeczki Listeria monocytogenes w zakażeniach ludzi. Przegl Epidemiol 2011; 65: 57-62.

8. Kołakowska A, Madajczak G. Genetyczne metody typowania pałeczek Listeria monocytogenes. Przegl Epidemiol 2011; 65: 421 - 7.

9. Lewańska M, Godela A, Myga-Nowak M. Listerioza - współczesne postrzeganie zagrożenia epidemiologicznego. Post Mikrobiol, 2018; 57: 106-16.

10. Madajczak G, Majczyna $D$. Serologiczne typowanie i genoserotypowanie pałeczek $L i$ steria monocytogenes izolowanych z próbek materiału klinicznego, próbek żywnosci i próbek środowiskowych. Med Dośw Mikrobiol 2009; 61: 79 - 85

11. Madajczak G, Szych J, Wojcik B, Mąka Ł, Formińska K. Validation of direct plating of a stool sample as a method for Listeria monocytogenes detection. Ann Agric Environ Med 2012; 19: 69-74.

12. Madajczak G. Porównanie testów do identyfikacji biochemicznej pałeczek Listeria sp. Diagnosta laboratoryjny nr 1 (30), 2013: 25-8.

13. Murray P., Rosenthal K., Pfaller M, Red. Przondo-Mordarska A. Mikrobiologia. Elsevier Urban \& Partner, Wrocław 2011, wyd.1, 249-52.

14. Muskalska K, Szymczak B. Postępy badań nad bakteriami rodzaju Listeria. Post Mikrobiol, 2015; 52: 123-32.

15. Rekomendacje postępowania w zakażeniach bakteryjnych ośrodkowego układu nerwowego. Rekomendacje diagnostyczno-terapeutyczno-profilaktyczne. Narodowy Instytut Leków, Warszawa, 2011.

16. Szewczyk E. Diagnostyka bakteriologiczna. Warszawa: Wydawnictwo Naukowe PWN SA, Warszawa 2013, s. 70-73, 348-349.

17. Szkaradkiewicz A. Mikrobiologia lekarska. Repetytorium z bakteriologii. Wydawnictwo Naukowe Uniwersytetu Medycznego w Poznaniu, Poznań 2011, 42-43.

18. Szych J, Madajczak G. Zakażenia i zatrucia wywołane przez bakterie rosnące w warunkach tlenowych. W: Etiologia, obraz kliniczny i diagnostyka ostrych zakażeń i zarażeń przewodu pokarmowego oraz zatruć pokarmowych. Red. Jagielski M. Fundacja Pro Pharmacia Futura, Warszawa 2010, 92-101.

19. Zakład Epidemiologii NIZP-PZH. Definicje przypadków chorób zakaźnych na potrzeby nadzoru epidemiologicznego stosowane w 2018 roku. Warszawa 2018, wersja 4, grudzień 2017, s. 40

Adres Autora: 00-791 Warszawa, ul. Chocimska 24, Zakład Bakteriologii i Zwalczania Skażeń Biologicznych Narodowego Instytutu Zdrowia Publicznego - Państwowego Zakładu Higieny w Warszawie 